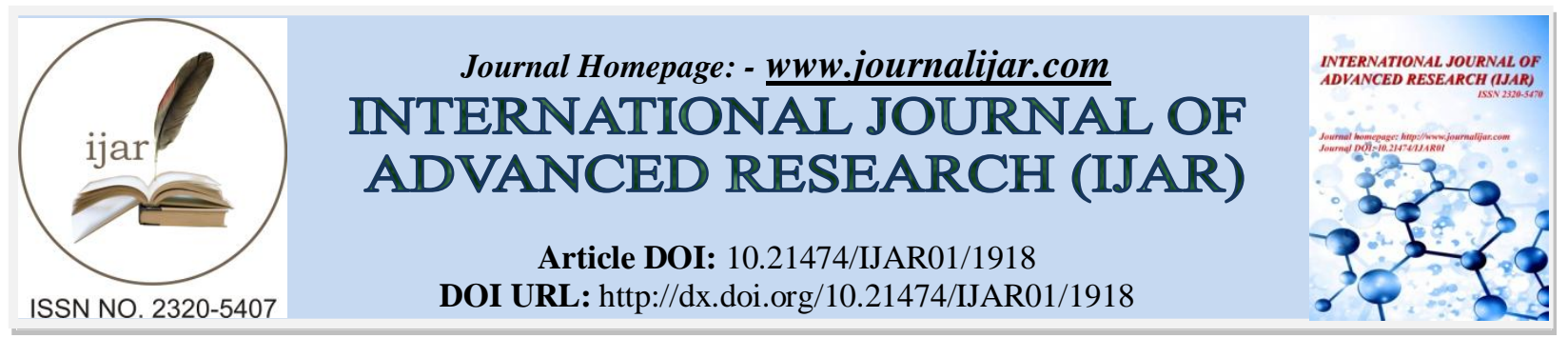

RESEARCH ARTICLE

\title{
DETECTION OF INFECTIOUS AGENTS IN BLOOD DONORS IN BASRA, IRAQ.
}

\section{Dr Dewan Abdullah and Dr Khairallah A S Mohammed.}

Department of Medical Laboratory Technology, College of Health and Medical Technology, Southern Technical University, Basrah, Iraq.

\section{Manuscript Info}

Manuscript History

Received: 12 August 2016

Final Accepted: 22 September 2016

Published: October 2016

Key words:-

Infectious agents, HBV, HCV, Syphilis

\section{Abstract}

Transmission of infectious agents through donated blood is one of the major problems of blood transfusion. This is because of its essential role in the supportive care of medical and surgical patients. Total of 6536 (6517 male and 19 female) blood donor samples were collected from February to May 2016 and screened for human immunodeficiency virus (HIV), hepatitis B virus (HBV), hepatitis C virus (HCV) and syphilis. The study was carried out in blood bank in Basra city, Iraq. A total of 127 (1.94\%) donors have shown serological evidence of hepatitis B virus infection, $4(\mathbf{0 . 0 6 \%})$ showed HBsAg while $123 \mathbf{( 1 . 8 \% )}$ ) had positive anti-HBc results. The prevalence of anti-HCV, HIV, and syphilis was $9(0.13 \%), 0$ and 18 $(0.26 \%)$ respectively. There were no positive results among female donors.

Copy Right, IJAR, 2016,. All rights reserved.

\section{Introduction:-}

Transfusion transmitted infections (TTI) are the major concern of transfusion practice (1). Blood transfusion carries the risk of TTI including human immunodeficiency virus (HIV), hepatitis B virus (HBV), hepatitis C virus (HCV), syphilis and many other diseases (2).

In Iraq, studies showed that the prevalence of $\mathrm{HBV}$ infection has decreased from $4.1 \%$ to less than $1 \%$ in the period of seventies to nineties $(3,4)$. Regarding the prevalence of $\mathrm{HCV}$ infection was much lower than HBV infection among blood donors; anti-HCV rate was found to be $1.2 \%$ in Baghdad in year 2000(4). However, other study raised serious concerns regarding the $\mathrm{HBV}$ and $\mathrm{HCV}$ which were found to be intermediate to highly endemic infections in our country (5).

Screening of blood donors aims to ensure that blood provided for patients is as safe as possible. The selection of a proper screening assay is a major role to improve blood transfusion safety. The aim of this study was to screen the donated blood for four TTIs with quality assured system. Surface antigen (HBsAg) and the antibody to the hepatitis $\mathrm{B}$ core antigen (anti-HBc) and anti-HCV were used to detect hepatitis B virus (HBV) and hepatitis C virus (HCV), respectively. Using of $\mathrm{HBsAg}$ and anti-HBc screening tests of blood donations might prevent HBV transmission from HBsAg-negative blood donors.

According to the National AIDS Control Organization (NACO) guidelines all blood sample were tested for human immunodeficiency virus (HIV) 1 and 2. 
A specific treponemal test for syphilis (Treponema pallidum hemagglutination assay, TPHA) was used for estimation of syphilis infection.

Materials and methods:-

All blood donors are routinely screened for the presence of serological evidence of HBV, HCV, HIV, and syphilis infection. Demographic data which included age and sex were collected from the record of Central Blood Bank (in Basra city centre). A proper sample of all blood donors during the study period from 1 February to 12 May 2016 was included in the study. Different age groups were included in the study. Five millilitres of blood was collected from each donor and was stored at $4{ }^{\circ} \mathrm{C}$ until tested as per the blood banks and kits manufacturers' recommendations. Testing is always performed on the same day. Blood samples were tested for HBsAg, antibodies to anti-HBc, antibodies to hepatitis C antigen (anti-HCV), antibodies to human immunodeficiency virus (HIV) $1 \& 2$ and antibodies to Treponema pallidum by the ELISA kit (BioKits).

\section{Results:-}

Total of 6536 blood donations in Basra governorate (6517 males and 19 females) were screened for HBV, HCV, $\mathrm{HIV}$, and syphilis infections. The age of the participants ranged from 19 to $>50$ years. There was no positive result among female donors. A total of $154(2.36 \%)$ donors were found to have one or more positive screening test result (table 1). Regarding the screening for HBV, 127 (1.94\%) donors have shown serological evidence for HBV infection; $123(1.8 \%)$ donors had positive test results for anti-HBc, and $4(0.06 \%)$ donors had positive test results for HBsAg (table 1). For the screening for the anti-HCV antibody $9(0.13 \%)$ donors had positive results (table 1$)$. Regarding the screening of syphilis infection $18(0.26 \%)$ donors showed positive results (table 1$)$, while none of the donors have shown positive results for HIV infection (table 1). The positive results were distributed over different blood group but $\mathrm{AB}+$ and $\mathrm{A}+$ showed highest prevalence of $\mathrm{HBV}, \mathrm{HCV}$ and syphilis infections (table 2).

Table 1:- Age distribution of donors and their test results.

\begin{tabular}{|l|c|c|c|c|c|c|c|}
\hline \multicolumn{1}{|c|}{ Age } & HBsAg & HBcAb & HCV & HIV & TPHA & $\begin{array}{c}\text { Total } \\
\text { Positive }\end{array}$ & Total tested \\
\hline $19-30$ & 0 & 21 & 2 & 0 & 4 & 27 & \\
\hline $30-40$ & 1 & 55 & 6 & 0 & 8 & 70 & \\
\hline $40-50$ & 1 & 34 & 1 & 0 & 6 & 42 & \\
\hline$>50$ & 2 & 13 & 0 & 0 & 0 & 15 & \\
\hline TOTAL & 4 & 123 & 9 & 0 & 18 & 154 & 6536 \\
& $(0.06 \%)$ & $(1.8 \%)$ & $(0.13 \%)$ & & $(0.26 \%)$ & $(2.36 \%)$ & \\
\hline
\end{tabular}

Table 2:- blood group distribution of donors and their results.

\begin{tabular}{|l|c|c|c|c|c|c|}
\hline \multicolumn{1}{|c|}{ Blood Group } & HBsAg & HBcAb & HCV & HIV & TPHA & $\begin{array}{c}\text { Total } \\
\text { Positive results }\end{array}$ \\
\hline $\mathrm{A}$ & $\begin{array}{c}2 \\
(50 \%)\end{array}$ & $40(32.5 \%)$ & $2(22.2 \%)$ & 0 & $6(33.35 \%)$ & $\mathbf{5 0}(\mathbf{3 2 \%})$ \\
\hline $\mathrm{B}$ & $\begin{array}{c}2 \\
(50 \%)\end{array}$ & $24(19.5 \%)$ & $2(22.2 \%)$ & 0 & $5(27.7 \%)$ & $\mathbf{3 3}(\mathbf{2 1 . 4 \% )})$ \\
\hline $\mathrm{AB}$ & 0 & $30(24.35)$ & $4(44.4 \%)$ & 0 & $5(27.7 \%)$ & $\mathbf{3 9}(\mathbf{2 5 . 3 \% )}$ \\
\hline $\mathrm{O}$ & 0 & $2923.5 \%)$ & $1(11.1 \%)$ & 0 & $2(11.1 \%)$ & $\mathbf{3 2 ( 2 0 . 8 \% )}$ \\
\hline $\begin{array}{l}\text { TOTAL positive } \\
\text { results }\end{array}$ & $\mathbf{4}$ & $\mathbf{1 2 3}$ & $\mathbf{9}$ & $\mathbf{0}$ & $\mathbf{1 8}$ & $\mathbf{1 5 4}$ \\
\hline $\mathrm{RH}-$ & 1 & 21 & $2(22.2 \%)$ & 0 & $4(22.2 \%)$ & $\mathbf{2 8}(\mathbf{1 8 . 8 \%})$ \\
\hline RH + & $\begin{array}{c}(25 \%) \\
(75 \%)\end{array}$ & $102(82 \%)$ & 7 & 0 & 14 & $\mathbf{1 2 6}(\mathbf{8 1 . 8 \%})$ \\
\hline $\begin{array}{l}\text { TOTAL positive } \\
\text { results }\end{array}$ & $\mathbf{4}$ & $\mathbf{1 2 3}$ & $\mathbf{9}$ & $\mathbf{0}$ & $\mathbf{1 8}$ & $\mathbf{1 5 4}$ \\
\hline
\end{tabular}




\section{Discussion:-}

Results showed that the seroprevalence of $\mathrm{HBV}$ and HCV among blood donors in Basra governorate, the finding indicates a low level of HBV and HCV seroprevalence. The study showed that the seroprevalene of $\mathrm{HBs} A g$ is in lower rate if compared to previous studies conducted in Baghdad (0.6\%), Bablyon, $(0.7 \%)$ and Basra governorate $(0.2 \%) 4,5,6)$. The study showed that the prevalence of HCV antibodies was 0.1 among blood donors which is similar to a previous study carried out in Basra city (6). Comparing our result with the results of other studies in Baghdad $(0.6 \%)$ and Babylon governorate $(0.7 \%)$ showing that Basra city has a lower prevalence of $\mathrm{HCV}$ infection in blood donors.

On comparison our results with others in neighboring countries (Kuwait, Jordan and Iran) the prevalence of $\mathrm{HBsAg}$ and $\mathrm{HCV}$ in those countries is higher than that in Basra governorate $(7,8,9,10)$.

The present results found that, the higher HBV seroprevalence was found to be higher significantly in age $\geq 40$ years and this result is consistent with others $(4,5,6)$, this may be because these age groups have higher chance for exposure to HBV infection and sexual activity. Regarding the age distribution of anti-HCV the higher prevalence age was $\geq 30$ years. For syphilis, the seroprevalence was found to be $0.26 \%$ in our study. Findings of the present study also revealed that the higher HBV and HCV in group seroprevalence was found in blood groups $\mathrm{A}+$ and $\mathrm{O}+$.

Knowing the seroprevalence of HIV, HBV, HCV and syphilis among blood donors is a valuable information which will help us to know the unseen percentage of infections that prevails in the community and to minimise risk of transfusion transmissible infectious agents through blood transfusion.

\section{References:-}

1. Bihl F., Castelli D., Marincola F., Dodd R. Y. \& Brandes C (2007). Transfusion transmitted infections; J Transl Med.

2. Moor A. C. E., Dubbelman T. M. A. R., VanSteveninck J. \& Brank A (1999). Transfusion transmitted diseases: risks, prevention and perspectives. Eu J Haematol; 62: 1-18.

3. Ataallah TM, Hanan KA, Maysoun KS, et al. (2011). Prevalence of hepatitis B and C among blood donors attending the National Blood Transfusion Center in Baghdad, Iraq from 2006-2009. Saudi Med J; 32:1046-50.

4. Al-Juboury AWF, Salih HA, Al-Assadi MK, et al. (2010). Seroprevalance of hepatitis B and C among blood donors in Babylon Governorate- Iraq. Med J Babylon. 7:1-2.

5. Arwa H. Al -Hamdani, Sarab K. Al-Rawy, Hind A. Khamees (2012). Retrospective Seroprevalence Study of Hepatitis B and C in Iraqi Population at Baghdad: A Hospital Based Study; Iraqi J. Comm. Med., July (3).

6. Ali Al-Rubaye, Ziad Tariq, Laith Alrubaiy (2016). Prevalence of hepatitis B seromarkers and hepatitis C antibodies in blood donors in Basra, Iraq; BMJ Open astro ;3

7. Ameen R, Sanad N, Al-Shemmari S, et al. (2005). Prevalence of viral markers among first-time Arab blood donors in Kuwait. Transfusion; 45:1973-80.

8. Al-Gani EA. Prevalence of HBV, HCV and HIV-1, 2 (2012). Infections among blood donors in Prince Rashed Ben Al-Hassan Hospital in North Region of Jordan. Int J Biol Med Res; 2:912-16.

9. Alavian SM, Hajarizadeh B, Ahmadzad-Asl M, Kabir A, Bagheri-Lankarani K. (2008). Hepatitis B Virus infection in Iran: A systematic review. Hepat Mon.; 8 (4):281-94.

10. Alavian SM, Tabatabaei SV, Ghadimi T, Beedrapour F, Kafi-Abad SA, Gharehbaghian A, et al. (2012). Seroprevalence of Hepatitis B Virus Infection and Its Risk Factors in the West of Iran: A Population-based Study. Int J Prev Med.; 3 (11):770-5. 